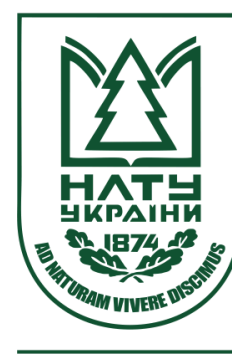

Науковий вісник НЛТУ України Scientific Bulletin of UNFU

https://nv.nltu.edu.ua

https://doi.org/10.15421/40290503

$@ \bowtie$ Correspondence author

Article received 14.05.2019 p.

Article accepted 30.05.2019 p.

S. M. Pidkhovna

УДК 712.2:582.091/.097(477.41/.42)

Н. О. Олексійченко ${ }^{1}$, С. М. Підховна ${ }^{2}$

${ }^{1}$ Національний університет біоресурсів і природокористування України, м. Київ, Украӥна ${ }^{2}$ ВП НУБіП Украӥни "Бережанський агротехнічний інститут", м. Бережани, Україна

\title{
РЕТРОСПЕКТИВНИЙ АНАЛІЗ ФОРМУВАННЯ ПАРКІВ-ПАМ'ЯТОК САДОВО-ПАРКОВОГО МИСТЕЦТВА ТЕРНОПІЛЬЩИНИ
}

\begin{abstract}
Наведено результати ретроспективного аналізу формування та розвитку парків-пам'яток садово-паркового мистецтва Тернопільщини та виявлено п'ять історичних періодів їхнього становлення. Найактивніше розбудову паркових територій, які нині є об'єктами культурної спадщини, проводили у XVIII-XIX ст., саме в цей період створено одинадцять дослідних парків. Наведено типологічну класифікацію об'єктів за різними характеристиками (заповідним статусом, розташуванням, періодом створення, величиною і напрямом планування). Відзначено залежність архітектурно-планувального рішення парків від часу створення. Встановлено, що за показниками видового складу найбільші колекції деревних рослин $\epsilon$ у Раївському, Скала-Подільському і Коропецькому парках. Встановлено перспективність використання паркових ресурсів у збагаченні видового і формового різноманіття краю. Проаналізовано підпорядкування дослідних парків і запропоновано напрями їх раціонального використання на сучасному етапі та популяризації природно-заповідних об'єктів й залученню інвестицій у розвиток рекреації у Тернопільській області. З'ясовано, що для успішного функціонування парків та забезпечення відповідного режиму користування наявних функціональних зон потрібно розробити проектну організацію території парків, здійснити організаційно-охоронні заходів для збереження окремих елементів паркового середовища.
\end{abstract}

Ключові слова: типологічний і ландшафтно-планувальний аналіз; періодизація; історія створення парків; таксономічний склад.

Вступ. Наслідком складного історико-географічного розвитку Тернопільщини $є$ накладання на іï теренах трьох великих історичних територій - Галичини, Волині та Поділля (Syvyi, 2017). 31387 р. землі Подолії, Галичини, Волині упродовж декількох століть були під владою Польщі. Зв'язок української культури з польською, литовською, західноєвропейською залишив глибокий слід у розвитку українського паркового мистецтва (Dudyn, 2016).

У польсько-литовський період сформувалася сучасна мережа поселень Тернопільщини. Саме на час, що тривав із середини XIV ст. до другої половини XVIII ст., припадає понад 85 \% усіх перших згадок про сучасні населені пункти області (Syvyi, 2017). Загалом тут виявлено понад 120 населених пунктів, в яких збереглися або колись існували замки, оборонні двори, фортеці, фортифіковані міста, оборонні монастирі та храми (Zamky Ternopillia, 2007). Сучасна Тернопільська обл.

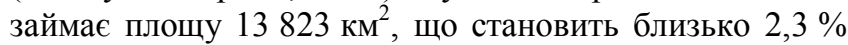
від території України і 10,5\% від Західного регіону держави. За схемою фізико-географічного районування України вся територія Тернопільської обл. розташована у зоні широколистяних лісів на стику чотирьох фізикогеографічних областей - Малого Полісся (крайній пів- нічний захід), Середньоподільської височинної (північний схід), Західноподільської височинної (центр і південь) і Розтоцько-Опільської горбогірної (захід) областей (Rudenko, 2007).

Природно-заповідний фонд Тернопільщини має природоохоронну, наукову, естетичну і рекреаційну цінність та слугує збереженню природної різноманітності ландшафтів, генофонду тваринного і рослинного світу, підтриманню загального екологічного балансу і забезпеченню фонового моніторингу навколишнього природного середовища (Cherniak et al., 2014). До об'єктів природно-заповідного фонду Тернопільської обл. занесено 28 парків колекційного блоку чотирьох категорій заповідності. Серед них 15 парків-пам'яток садово-паркового мистецтва загальною площею 120,63 га, 9 дендрологічних парків - 109,7 га, 3 ботанічні сади - 232,86 га i один зоологічний парк місцевого значення площею 10 га. Фактична площа природно-заповідного фонду Тернопільської обл. становить 123228,07 га. Показник заповідності Тернопільської обл. становить 8,91 \% (Perelik terytorii, 2018).

Доцільність аналізу характеристик об'єктів культурної спадщини за роками або історичними періодами зумовлена потребою визначення змін, які відбувалися уп-

Інформація про авторів:

Олексійченко Надія Олександрівна, д-р с.-г. наук, професор, кафедра ландшафтної архітектури та фітодизайну. Email: noolex@bigmir.net

Підховна Світлана Михайлівна, асистент, кафедра лісового і садово-паркового господарства. Email: pidkhovna_s@ukr.net

Цитування за ДСту: Олексійченко Н. О., Підховна С. М. Ретроспективний аналіз формування парків-пам'яток садово-паркового мистецтва Тернопільщини. Науковий вісник НлтУ України. 2019, т. 29, № 5. С. 17-21.

Citation APA: Oleksiichenko, N. O., \& Pidkhovna, S. M. (2019). Retrospective Analysis of the Park-Monuments of Landscape Architecture of Ternopil Region. Scientific Bulletin of UNFU, 29(5), 17-21. https://doi.org/10.15421/40290503 
родовж функціонування парків, їх естетична, композиційна й історична цінність, а також символічне значення, що визначається соціально-політичними та ідеологічними міркуваннями, які змінюються внаслідок постійного розвитку суспільства (Gatalska, 2017).

Значний внесок у дослідження парків-пам'яток садово-паркового мистецтва Тернопільської обл. зробили такі автори: природну та інтродуковану дендрофлори окремих парків дослідного регіону досліджували В. М. Черняк (Cherniak, 2004), В. Я. Заячук (Zaiachuk, 2012), Н. К. Бут (But, 2010); Ю. О. Клименко аналізував динаміку кількості видів і культиварів та охарактеризував ландшафти Більче-Золотецького, Раївського, Вишнівецького i Скала-Подільського парків (Klymenko, 2006). У публікації Н. О. Олексійченко і С. М. Підховної (Oleksiichenko \& Pidkhovna, 2018) наведено дані щодо сучасного стану збереження вікових дерев та їх кількісної структури у парках-пам'ятках садово-паркового мистецтва Тернопільщини.

Зазначені вище дослідження дослідних об'єктів не поєднані комплексним аналізом. Тому проведення ретроспективного та інтегрального аналізу формування заповідної паркової мережі Тернопільщини нині $є$ актуальним.

Об'єкт дослідження - парки-пам'ятки садово-паркового мистецтва Тернопільщини.

Предмет дослідження - особливості формування та розвитку парків-пам'яток садово-паркового мистецтва Тернопільщини.

Мета досліджень - проведення ретроспективного аналізу формування та розвитку парків-пам'яток садово-паркового мистецтва Тернопільської області.

Періодизацію створення та аналіз типологічної характеристики об'єктів досліджень виконували за методикою Н. О. Олексійченко і Н. В. Гатальської (Oleksiichenko \& Gatalska, 2012). Під час проведення досліджень використовували типологічний, порівняльний, статистичний і аналітичний методи.
Матеріалами для дослідження слугували архівні матеріали (картографічні, іконографічні та письмова документація), сучасні наукові літературні джерела та результати натурного обстеження деревних насаджень, яке здійснювали маршрутно-візуальним шляхом із застосуванням Інструкції з інвентаризації зелених насаджень у містах та селищах міського типу України (Instruktsiia z inventaryzatsii, 2001).

Результати дослідження. У 1991 р. Тернопільську обл. поділено на 17 адміністративних районів. Дослідні об'єкти розташовані у 10 районах області (11 об'єктів) та у межах території Тернополя - 4 об'єкти (рис. 1).

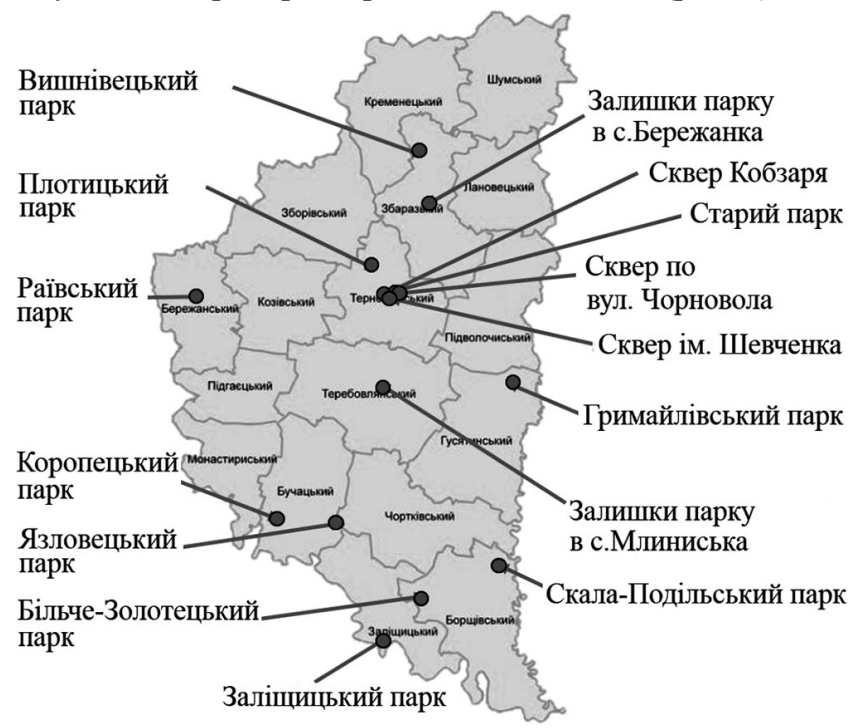

Рис. 1. Схема розміщення парків-пам'яток садово-паркового мистецтва на території Тернопільської області

Внаслідок проведених досліджень та опрацювання літературних джерел здійснено типологічний i ландшафтно-планувальний аналіз парків-пам'яток садовопаркового мистецтва Тернопільщини (таблиця).

Таблиця. Типологічна класифікація парків-пам'яток садово-паркового мистецтва

\begin{tabular}{|c|c|c|c|c|c|c|c|c|c|c|c|c|c|c|c|c|}
\hline \multirow[b]{2}{*}{$\begin{array}{c}\text { Класифіка- } \\
\text { ційна } \\
\text { одиниця }\end{array}$} & \multirow[b]{2}{*}{ Група } & \multicolumn{15}{|c|}{ Назва парку } \\
\hline & & 包 & 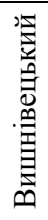 & 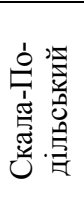 & 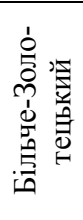 & 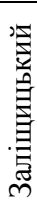 & 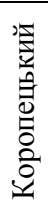 & 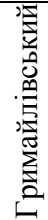 & 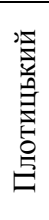 & 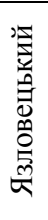 & 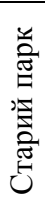 & 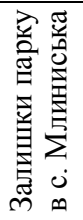 & 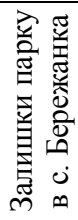 & 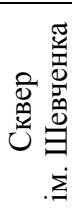 & 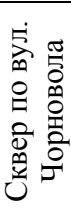 & 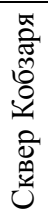 \\
\hline \multirow{2}{*}{ За значенням } & загальнодержавне & + & + & + & + & & & & & & & & & & & \\
\hline & місцеве & & & & & + & + & + & + & + & + & + & + & + & + & + \\
\hline \multirow{4}{*}{$\begin{array}{c}\text { За часом } \\
\text { закладення }\end{array}$} & XVII ст. & & & & & & & & & + & & & & & & \\
\hline & XVIII ст. & + & + & + & & & + & & + & & & + & & & & \\
\hline & XIX ст. & & & & + & + & & + & & & + & & + & & & \\
\hline & ХX ст. & & & & & & & & & & & & & + & + & + \\
\hline \multirow{2}{*}{$\begin{array}{c}\text { За величи- } \\
\text { ною }\end{array}$} & малі & & + & & & + & + & & + & + & + & + & + & + & + & + \\
\hline & середні & + & & + & + & & & + & & & & & & & & \\
\hline \multirow{3}{*}{$\begin{array}{c}\text { За напрямом } \\
\text { планування }\end{array}$} & регулярні & & & & & + & & & & + & & & & + & + & + \\
\hline & пейзажні & + & & + & + & & + & + & + & & & + & + & & & \\
\hline & змішаного типу & & & & & & & & & & + & & & & & \\
\hline \multirow{2}{*}{$\begin{array}{c}\text { За місцем } \\
\text { розташуван- } \\
\text { ня }\end{array}$} & $\begin{array}{c}\text { сільські } \\
\text { (в т.ч. селищні) }\end{array}$ & + & + & + & + & & + & + & + & + & & + & + & & & \\
\hline & міські & & & & & + & & & & & + & & & + & + & + \\
\hline
\end{tabular}

Серед парків-пам'яток садово-паркового мистецтва Тернопільської обл. тільки 4 об'єкти мають загальнодержавне значення ("Більче-Золотецький", "Раївський", "Вишнівецький", "Скала-Подільський"), всі інші - місцевого значення ("Гримайлівський", "Заліщицький",
"Коропецький", "Плотицький", "Язловецький", "Старий парк", залишки старовинних парків у с. Бережанка Лановецького р-ну та у с. Млиниська Теребовлянського рну, "Сквер по вул. Чорновола", "Сквер ім. Т. Шевченка", "Сквер Кобзаря"). Заповідний статус паркам нада- 
вали у різні періоди, зокрема, у 1960 р. (4 об'єкти), у 1968 p. (3 об'єкти), у 1977 р. (4 об'єкти), у 1994 р. (2 об'єкти) й у 2015 р. (2 об'єкти).

Парки було закладено у різні історичні періоди, починаючи з XVII ст. (рис. 2). Так, найстарішим об'єктом серед парків-пам'яток у дослідному регіоні $є$ "Язловецький парк", який розташований у с. Язловці Бучацького p-ну Тернопільської обл. Заклали парк шляхтичі Язловецькі. У середині XVIII ст. Язловець став власністю Понятовських. Вони перебудували нижній замок, на його місці звели палац, який зараз $\epsilon$ пам'яткою архітектури національного значення Тернопільської обл. (охоронний номер 1575). Парк розвивався і сформувався остаточно у XIX ст., коли палац перейшов у володіння монастиря Сестер Непорочного Зачаття Пресвятої Діви Марії. Його засновницею була Марцеліна Даровська. Сестри-непорочниці заклали новий сад, насадили виноградник, створили оранжерею. У далекому західному куті парку черниці організували монастирську усипальницю. 3 приходом радянської влади, у 1946 р. монастир було закрито. У будівлі колишнього палацу розмістився санаторій. Тільки у 1997 р. дали дозвіл відновити монастир. На сьогодні монастирю передано тільки частину палацу, в іншій, як і раніше, розміщено санаторій, якому належить значна частина парку. Рішенням Тернопільської обласної ради від 15 жовтня 2015 р., № 2013 Язловецькому парку було надано статус пам'ятки садово-паркового мистецтва.

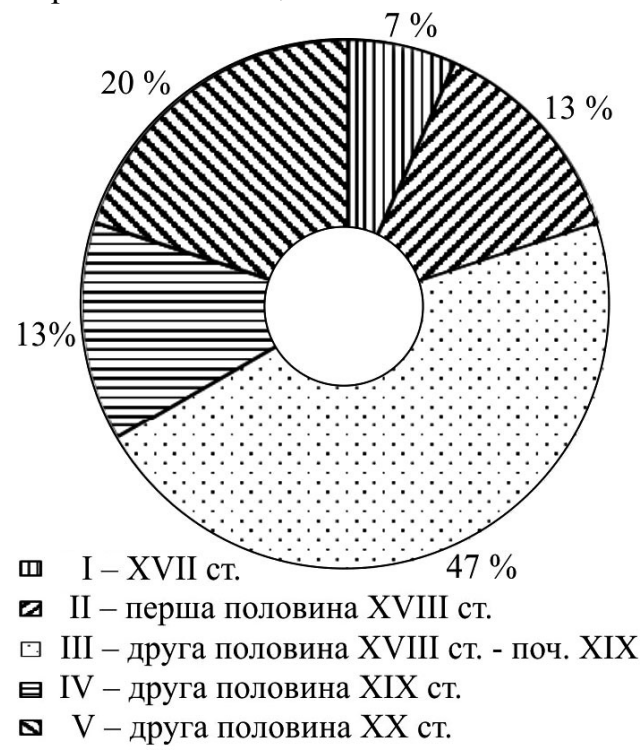

Рис. 2. Розподіл парків-пам'яток Тернопільщини за історичним періодом їх створення

Найактивніше розбудову паркових територій, які нині є об'єктами культурної спадщини нашої країни, проводили у XVIII-XIX ст., саме в цей період з'явилося 11 парків, де за результатами натурних обстежень виявлено архітектурні споруди, що мають культурно-історичну цінність і потребують невідкладних заходів збереження, консервації і реставрації.

Із замкових територій трансформовані чотири об'єкти (Язловецький, Гримайлівський, Вишнівецький і Плотицький), всі інші засновані на новому місці. За місцем розташування переважають парки, які перебувають у сільській місцевості (67 \%), у межах міської місцевості розташовані: Заліщицький парк, Старий парк, "Сквер по вул. Чорновола", "Сквер ім. Т. Шевченка" і "Сквер Кобзаря". Загальна площа парків-пам'яток садово-пар- кового мистецтва Тернопільщини становить 120,69 га, серед яких найбільшим $є$ "Скала-Подільський парк" (26 га). Найменшу площу має "Сквер Кобзаря" - всього тільки 0,32 га. Більшість парків-пам'яток переважно малі за площею (73 \%), середню за розміром площу мають тільки чотири об'єкти (Раївський, Скала-Подільський, Більче-Золотецький та Гримайлівський).

Парки-пам'ятки перебувають у підпорядкуванні комунальних підприємств (27\% від загальної кількості), селищних та міських рад $(27 \%)$, лікувальних та оздоровчих закладів (20\%), навчальних закладів (13\%), лісомисливського господарства (7 \%) і національного заповідника (7 \%). Здебільшого таке підпорядкування має тільки негативні наслідки, оскільки більшість цих організацій не мають жодного відношення до паркового будівництва. За складом насаджень парки-пам'ятки Тернопільщини переважно сформовані на основі місцевої флори із широким застосуванням інтродуцентів. Насадження парків-пам'яток за результатами проведених обстежень потребують заходів 3 відновлення та реконструкції, оскільки вони зазнали негативних змін за період війн і радянських часів.

Найбільші колекції деревних рослин представлені у Раївському (98 видів і культиварів), Скала-Подільському (67) і Коропецькому (61) парках, дещо менші (від 40 до 48 видів) у Більче-Золотецькому, Плотицькому, Заліщицькому, Гримайлівському і Старому парку, у всіх інших парках значно менші колекції деревних рослин (рис. 3). Колекції деревних рослин упродовж історичного розвитку у Скала-Подільському, Раївському і Коропецькому парках зазнали значних втрат.

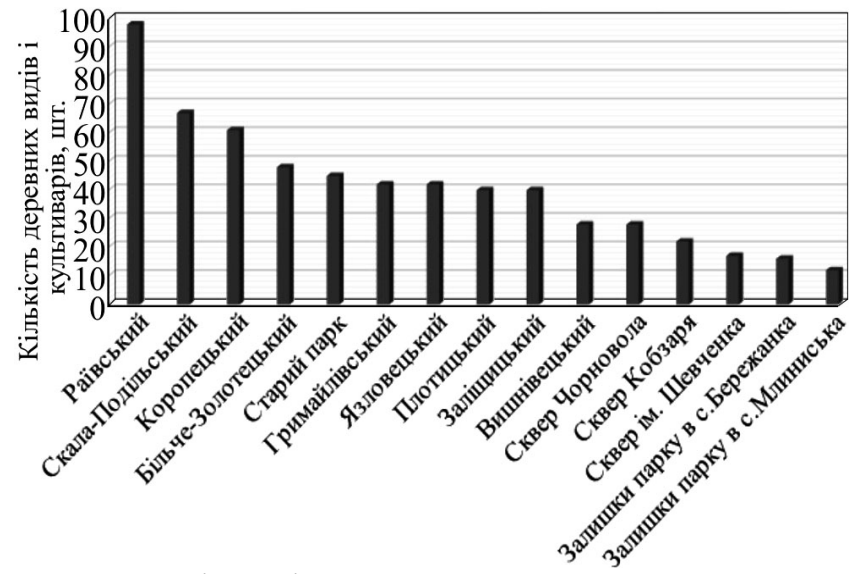

Рис. 3. Розподіл парків-пам'яток садово-паркового мистецтва Тернопільщини за кількістю деревних видів та культиварів

У межах дослідних парків виявлено 129 вікових дерев, які представлені 30 видами та двома культиварами, 3 яких - 24 представники відділу покритонасінних. Аборигенні вікові дерева представлені 11 видами, що становить 37,5 \% від їх загальної кількості. Вікові екземпляри деревних інтродуцентів виявлено на території восьми парків (Більче-Золотецькому, Заліщицькому, Раївському, Скала-Подільському, Плотицькому, Коропецькому, Гримайлівському парках та в залишках парку с. Млиниська).

У ландшафтно-архітектурному рішенні парків-пам'яток садово-паркового мистецтва Тернопільщини характерним $є$ поєднання різноманітних композиційних засобів і художніх прийомів різних епох. Кожен парк $є$ об'ємно-просторовою композицією, побудованою за певним задумом, з усіма стилістичними особливостями, 
що відповідають періоду їі створення. Під час аналізу планувального рішення територій парків-пам'яток садово-паркового мистецтва Тернопільської обл. виявлено, що переважають парки із ландшафтним плануванням (54 \% від загальної кількості парків), об'єкти із регулярним плануванням становлять 33 і $13 \%$ - iз змішаним плануванням.

За результатами проведених досліджень встановлено, що планувальна структура двох парків (залишки старовинних парків у селах Бережанка та Млиниська) зазнала істотних порушень і не відповідає періоду розквіту. Наявні збережені основні елементи центральної частини композиції планувальної структури періоду розквіту та інших періодів у Раївському, Більче-Золотецькому, Плотицькому, Коропецькому парках. Найкраще збережену планувальну структуру мають сучасні об'єкти - парки-пам'ятки садово-паркового мистецтва м. Тернополя (Сквер по вул. Чорновола, Сквер ім. Т. Шевченка, Сквер Кобзаря), де планувальна структура $є$ цілісною композицією із збереженими усіма елементами центральної частини, основними композиційними осями та акцентами.

Упродовж тривалого існування парки-пам'ятки піддаються різним негативним впливам. Проведені дослідження у старовинних парках ілюструють серйозні проблеми, пов'язані з нерегульованим розвитком паркових фітоценозів, що призвело до руйнувань структури угруповань і погіршення санітарного стану насаджень. Для успішного утримання парків-пам'яток Тернопільщини потрібно проводити безперервний догляд за ними, оптимізувати їх фітоценотичну структуру, здійснювати просторове формування, проводити боротьбу з негативними зовнішніми впливами.

Оскільки парки мають значну історико-культурну цінність, то потрібно здійснювати організаційно-охоронні заходи з консервації вікових насаджень та відновлення старовинних елементів. Також є нагальна потреба у розробленні проектів організації території дванадцятьох парків, проведенні організаційно-охоронних заходів для забезпечення відповідного режиму користування їх функціональних зон.

Отже, у парках-пам'ятках садово-паркового мистецтва Тернопільщини доцільно здійснити комплекс науково обгрунтованих заходів відновлення щодо поліпшення їх територіальної організації та ландшафтнокомпозиційних характеристик.

Висновки. Ретроспективний аналіз формування парків-пам'яток садово-паркового мистецтва Тернопільської обл. показав потребу розроблення заходів з їх збереження та відновлення, оскільки вони мають велике природоохоронне, наукове, естетичне, оздоровче і виховне значення і відіграють вагоме значення у формуванні мережі заповідних об'єктів.

Найактивніше розбудову паркових територій, які нині є об'єктами культурної спадщини, проводили у XVIII-XIX ст., саме в цей період створено одинадцять дослідних парків. Унаслідок проведеного типологічного і ландшафтно-планувального аналізу парків-пам'яток садово-паркового мистецтва Тернопільської обл. виявлено, що більшість 3 них мають статус місцевого значення (73\%), розташовані у сільській місцевості (67\%), 73 \% 3 них - малі за площею, 11 парків закладено у XVIII-XIX ст. За показниками видового складу найбіль- ші колекції деревних рослин представлені у Раївському (98 видів і культиварів), Скала-Подільському (67) і Коропецькому (61) парках.

Старовинні парки Тернопільщини потребують реконструктивних та заходів з консервації, які забезпечували б їх культурну цінність, автентичність та цілісність. Аналіз сучасного стану та дослідження потенціалу розвитку й туристичної привабливості парківпам'яток садово-паркового мистецтва може сприяти пошуку реальних напрямів популяризації природно-заповідних територій та об'єктів, що сприятиме залученню інвестицій у розвиток рекреації в Тернопільській області.

\section{Перелік використаних джерел}

But, N. K. (2010). Introdutsenty v nasadzhenniakh parku-pamiatky sadovo-parkovoho mystetstva "Rai" u s. Rai Berezhanskoho raionu Ternopilskoi oblasti. Introduktsiia roslyn, zberezhennia ta zbahachennia bioriznomanittia $v$ botanichnykh sadakh $i$ dendroparkakh: Materials of International Scientific Conference, (pp. 391-392). Kyiv: Fitosociocentr. [In Ukrainian].

Cherniak, V. M. (2004). Kultyvovana dendroflora Volyno-Podillia, perspektyvy yii vykorystannia ta zbahachennia. Ternopil: TNPU im. V. Hnatiuka, 264 p. [In Ukrainian].

Cherniak, V. M., Synytsia, H. B., \& Piatkivskyi I. O. (2014). Unique pearls of nature of Ternopil region. Ternopil: Educational bookBogdan. [In Ukrainian].

Dudyn, R. B. (2016). Konservatsiia, restavratsiia ta rekonstruktsiia sadovo-parkovykh obiektiv. Lviv: Kompaniia "Manuskrypt", 192 p. [In Ukrainian].

Gatalska, N. V. (2017). Scientific and methodological approaches of cultural and historical evaluation of parks. Scientific Bulletin of UNFU, 27(4), 32-35. https://doi.org/10.15421/40270406

Instruktsiia z inventaryzatsii. (2001). Pro zatverdzhennia Instruktsii z inventaryzatsii zelenykh nasadzhen u naselenykh punktakh Ukrainy vid 24.12.2001 r., № 226. Nakaz Derzhavnoho komitetu budivnytstva, arkhitektury ta zhytlovoi polityky Ukrainy. Retrieved from: http://zakon5.rada.gov.ua/laws/show/z0182-02. [In Ukrainian].

Klymenko, Yu. O. (2006). Derevni nasadzhennia starovynnykh parkiv Ternopilskoi oblasti. (Ser. Biolohiia). Naukovi zapysky Ternopilskoho natsionalnoho pedahohichnoho universytetu im. Volodymyra Hnatiuka, 3-4(30), 3-10. [In Ukrainian].

Klymenko, Yu. O. (2006). The dynamics of species and cultivars quantity and description of landscapes of ancient memorial parks of national significance in Ukrainian Polissya and Forest-Steppe. (Part 1). Agronomia, 74, 284-295. [In Ukrainian].

Oleksiichenko, N. O., \& Gatalska, N. V. (2012). Memorial parks of the garden art of the Central highland area of Dnipro river. (Part 2). Kyiv: TsP "KOMPRYNT". [In Ukrainian].

Oleksiichenko, N. O., \& Pidkhovna, S. M. (2018). The old-age trees of the parks-monuments as park and garden art objects in Ternopil region. Proceedings of the forestry academy of sciences of Ukraine, 16, 41-49. https://doi.org/10.15421/411805.

Perelik terytorii. (2018). Perelik terytorii ta obiektiv pryrodno-zapovidnoho fondu zahalnoderzhavnoho ta mistsevoho znachennia, roztashovanykh u Ternopilskii oblasti. Upravlinnia ekolohii ta pryrodnykh resursiv Ternopilskoi oblasnoi derzhavnoi administratsii. Retrieved from: http://ecoternopil.gov.ua/index.php/pryrodniresursy/pryrodno-zapovidnyi-fond/merezha-pzf. [In Ukrainian].

Rudenko, L. H. (2007). Natsionalnyi atlas Ukrainy. Kyiv: DNVP "Kartohrafiia", 440 p. [In Ukrainian].

Syvyi, M. Ia. (2017). Heohrafiia Ternopilskoi oblasti. Pryrodni umovy ta resursy. (Vol. 1). Ternopil: Vektor, 54 p. [In Ukrainian].

Zaiachuk, V. Ia. (2012). Struktura dendroflory Raivskoho parku. Scientific reports of the National University of Bioresources and Natural Resources of Ukraine, 171(1), 67-70. [In Ukrainian].

Zamky Ternopillia. (2007). Halytska brama. Nezalezhnyi chasopys, 56, 49-150. [In Ukrainian]. 
${ }^{1}$ National University of Life and Environmental Sciences of Ukraine, Kyiv, Ukraine ${ }^{2}$ Berezhany Agrotechnical Institute of National University of Life and Environmental Sciences of Ukraine, Berezhany, Ukraine

\section{RETROSPECTIVE ANALYSIS OF THE PARK-MONUMENTS} OF LANDSCAPE ARCHITECTURE OF TERNOPIL REGION

Parks-memorials of landscape architecture of Ternopil region are the valuable objects of landscape construction and have significant natural and scientific, historical and memorial, cultural, aesthetic and social values. Under the influence of historical events, social and economic circumstances, human activity and the destructive forces of time, the parks-memorials of landscape art of Ternopil region underwent the significant changes of original look and functional purpose, which lead to the relevance of retrospective investigations, dendroflora structure studying, territorial organization and development of scientifically grounded measures concerning the preservation and maintenance of these parks. In Ternopil region there are 15 parks-memorials of landscape art, which belong to the nature reserve fund of Ukraine. Among these, memorials of landscape art of national importance like BilcheZolotetskyi, Vyshnivetskyi, Rayivskyi, and Skala-Podilskyi parks are ancient historical parks that deserve the attention of domestic and foreign tourists. Hrymaylivskyi, Zalishchytskyi, Koropetskyi, Plotytskyi, Yazlovetskyi parks, Staryi Park inTernopol city are historical parks and are the memorials of landscape art of local importance. The remains of ancient parks in Berezhanka village, Lanovetsky district and in Mlynyska village, Terebovlya district deserve special attention among the parks that have some ancient trees and need the complete restoration. Among the parks, founded in the 20 century, the square on Chornovil Street, square named after Shevchenko, Kobzar's Square in Ternopil are referred to nature reserve fund of local importance. The main task facing all parks-memorials of landscape art is to preserve natural and artificial park landscapes, cultural heritage, valuable plants - invasive species, age and older long-lived trees on their territories, to do historical reconstruction of plantations and architectural forms according to projects of their maintenance and reconstruction. The analysis of the current state and research of the development potential and tourist attraction of park-monuments of landscape architecture can help find real ways to popularize nature-protected areas and objects, which will promote investment in the development of recreation in Ternopil region.

Keywords: typological and landscape-planning analysis; periodization; history of park creation; taxonomic composition. 